\title{
Modelling the impact of surplus pasture management techniques on production and profit in a pasture-based dairy system
}

\author{
K.T. WYNN ${ }^{1}$, P.C. BEUKES ${ }^{2}$ and A.J. ROMERA ${ }^{2}$ \\ ${ }^{1}$ DairyNZ, 259 Jordan Valley Road, RD1, Kamo 0185 \\ ${ }^{2}$ DairyNZ, Private Bag 3221, Hamilton 3240 \\ kate.wynn@dairynz.co.nz
}

\begin{abstract}
Three options for controlling surplus pasture on Northland dairy farms were modelled to determine the impact of each on production and operating profit. The three options were a) Light cut, fixed break size (LCFB): Paddock cut for silage as soon as surplus was identified. No effect on rotation length. b) Bulk cut, fixed break size (BCFB): Paddock closed until cover of $4000 \mathrm{~kg}$ dry matter $(\mathrm{DM}) /$ ha was reached then cut for silage. Rotation length was shortened. c) Bulk cut, variable break size (BCVB): Paddock closed until cover of 4000 $\mathrm{kg} \mathrm{DM} / \mathrm{ha}$ was reached then cut for silage. Rotation length was maintained thus reducing available grazing area. The hypothesis was that LCFB would translate into the most profitable option as pasture is being cut as soon as a genuine surplus is realised, optimising silage feed quality. Results showed LCFB to be $\$ 100 /$ ha more profitable (operating profit) compared with BCFB and $\mathrm{BCVB}$ at only one of the three sites investigated $(\mathrm{P}<0.05)$. The LCFB option resulted in a significantly higher $(\mathrm{P}<0.05)$ pasture yield at both the Northland Agricultural Research Farm and Whangarei sites, however, there was no effect of silage-making option on milk production at any of the sites. This modelling exercise showed that LFCB was not consistently more profitable across sites, that it is a simplification to assume that "one size fits all" and that the same pasture conservation rules can be applied across different sites and pasture types. This suggests that farmers can be flexible in choosing pasture conservation practices to help balance competing demands on labour and other resources without risking a loss in profit.
\end{abstract}

Key words: dairy farm, pasture surplus, production, profit, whole farm model

\section{Introduction}

The management of surplus pasture on a dairy farm is challenging and occasionally problematic. If average pasture cover becomes too high, the quality of feed and sward regrowth can suffer, resulting in a decline in production. High pre-grazing covers $(>3000 \mathrm{~kg}$ dry matter (DM)/ha) will reduce the quality of the feed offered, and by forcing cows to graze to $1500 \mathrm{~kg} \mathrm{DM} / \mathrm{ha}$ post-grazing residual, cow intake will be compromised.
However, a surplus can quickly become a deficit if too great an area is conserved or pasture growth rates are variable from one week to the next resulting in underfed cows. It is costly to get it wrong and then have to feed out recently made silage. A delicate balancing act exists between feeding the cows now and saving forage for the future.

Pasture surpluses generally occur after balance date (when pasture growth rate equals feed demand). Traditionally, balance date is 50-60 days after the planned start of calving of mixed age cows, but there are both regional and management-induced differences. In determining whether to conserve pasture through silage-making, three questions need to be asked: 1) is there a genuine surplus now 2) will there be a surplus in the near future and 3) which paddock(s) should be closed for conservation?

There are a number of methods of conserving pasture and, depending on the method chosen, this will have on-going implications for other parameters on the farm such as feed availability and quality, rotation length, cow condition and milk production.

DairyNZ's Whole Farm Model (WFM) was used to evaluate the production and economic impacts of three different options of managing a pasture surplus. These options were:

1. Light cut, fixed break size (LCFB): After closing a paddock, it was cut immediately and put back in the rotation with the assumption that silage quality would be higher (11 cf. $10 \mathrm{MJ} \mathrm{ME} / \mathrm{kg}$ DM) than the bulk cut options as herbage mass was not allowed to accumulate. The rotation length and break size did not change.

2. Bulk cut, fixed break size (BCFB): A closed paddock was left to accumulate herbage mass. With this option, break size was maintained on the remaining grazing area. This meant rotation length had to be shortened because part of the grazing area was closed for a period of time.

3. Bulk cut, variable break size (BCVB): A closed paddock was left to accumulate herbage mass. Planned rotation length was maintained on the remaining grazing area. Therefore, break size had to be reduced because the grazing area was now smaller (excludes the closed paddock). 
The hypothesis was that LCFB would translate into the most profitable option as pasture is being cut as soon as a genuine surplus is realised resulting in optimal silage feed. Other researchers have shown that postponing silage harvest date decreases digestibility and metabolisable energy in the silage crop (Marsh \& Ward 1978; McGrath et al. 1999; Randby et al. 2012).

\section{Methods}

\section{Basic model set-up}

The DairyNZ Whole Farm Model (WFM) version 4.9 was used for this exercise (see Beukes et al. (2008) for details of the model and its use). A baseline was established and the different treatments were imposed leaving all other parameters constant. No attempt was made to optimise the model for a particular parameter. Pasture growth in the WFM was driven by weather data (daily rainfall, radiation and temperature data supplied by NIWA) from Dargaville and Whangarei Climatological Stations and from a weather station on the Northland Agricultural Research Farm (NARF), $5 \mathrm{~km}$ north of Dargaville. The WFM uses the pasture (ryegrass/clover) growth model of McCall \& BishopHurley (2003). The kikuyu/ryegrass model was derived from the McCall model by using a scaling factor that moved more growth into summer and less in winter as evidenced by actual pasture growth data collected at NARF. The climate years used were 2004-2011, 2000 2011 and 1995- 2010 for the Dargaville, Whangarei and NARF sites, respectively. Pasture quality was not predicted by the model, but was user-defined for each month (default average over the year was $11 \mathrm{MJ} \mathrm{ME} / \mathrm{kg}$ DM). Pasture silage quality was also user-defined with two values used as the default based on which pasture conservation option was being modelled: $10 \mathrm{MJ} \mathrm{ME} /$ $\mathrm{kg} \mathrm{DM}$ for BCFB and BCVB, and $11 \mathrm{MJ} \mathrm{ME} / \mathrm{kg} \mathrm{DM}$ for LCFB. Molly is a mechanistic and dynamic model that simulates cow metabolism in the WFM (Hanigan et al. 2009), and represents the critical elements of digestion and metabolism of a dairy cow. In this exercise the Molly 4.2 version was used. Two pasture

Table 1. Predicted means and SED of operating profit (\$/ha) at three sites for different silage making options: Bulk cut, fixed break size (BCFB), Bulk cut, variable break size (BCVB) and Light cut, fixed break size (LCFB). * indicates significant treatment effect $(P<0.05)$

\begin{tabular}{lccc}
\hline & & Site & \\
& Dargaville & NARF & Whangarei \\
\hline BCFB & 1939 & 2386 & 2298 \\
BCVB & 1960 & 2390 & 2369 \\
LCFB & 1968 & 2418 & $2434^{\star}$ \\
SED & 32 & 20 & 27 \\
\hline
\end{tabular}

sward botanical compositions (predominately ryegrass/ clover and ryegrass/clover/kikuyu) were modelled to predict yield differences as these are the predominant pasture compositions in Northland. Ryegrass/clover/ kikuyu pastures are generally of a lower feed quality in summer/autumn than straight ryegrass/clover pastures. The kikuyu sward was assumed to make up $70 \%$ of the pasture available during summer/autumn.

A scaled-down farmlet of 16.8 ha (18 paddocks) was set up representing a typical Northland farm and incorporated farm parameters used at NARF. Scaling down was necessary to reduce model run times. The stocking rate was $3.3 \mathrm{cows} / \mathrm{ha}$. Maize silage was grown on-farm and annual yield was climate driven. The imported supplements, maize silage and palm kernel extract (PKE), were priced at $\$ 400 /$ tonne DM and economic input values for the 2007/08 season with a milk price of $\$ 7.37 / \mathrm{kg}$ milksolids (MS) were used. Silage making costs were assumed to be $\$ 180 / \mathrm{t} \mathrm{DM}$ for LCFB and \$120/t DM for the other two options, as there were higher machinery and labour costs associated with harvesting a light compared with a heavy cut.

The model was set up with management policies for post-grazing residuals $(>1200 \mathrm{~kg} \mathrm{DM} / \mathrm{ha})$, fertiliser application (170 kg N/ha/year), conservation and cutting of paddocks (cutting rules depending on the silage-making option simulated). Conservation time was assumed to be 15 September to 15 November. Silage making was only allowed when soil moisture levels dropped below $70 \%$ of field capacity to mimic the real life restriction of using heavy machinery on wet soils and causing damage. With the LCFB option, it was sometimes necessary to wait more than 30 days before harvesting paddocks to allow enough time for soils to dry out. Commonly used values for grass silage range from $9 \mathrm{MJ} \mathrm{ME} / \mathrm{kg} \mathrm{DM}$ (poor quality) to $11 \mathrm{MJ}$ ME/kg DM (good quality) (DairyNZ 2010). Values of 10 and $11 \mathrm{MJ} \mathrm{ME} / \mathrm{kg} \mathrm{DM}$ were assigned to all bulk cuts and light cuts, respectively.

An arbitrary decision was made that if a paddock was cut later than 30 days after closing for conservation,

Table 2. Predicted means and SED of pasture yield $(\mathrm{kg}$ $\mathrm{DM} / \mathrm{ha}$ ) at three sites for different silage making options: Bulk cut, fixed break size (BCFB), Bulk cut, variable break size (BCVB) and Light cut, fixed break size (LCFB). * indicates significant treatment effect $(P<0.05)$

\begin{tabular}{lccc}
\hline & \multicolumn{3}{c}{ Site } \\
& Dargaville & NARF & Whangarei \\
\hline BCFB & 12875 & 13618 & 13670 \\
BCVB & 12886 & 13627 & 13778 \\
LCFB & 12945 & $13742^{\star}$ & $13966^{\star}$ \\
SED & 62 & 39 & 52 \\
\hline
\end{tabular}


then the resultant silage quality would be $10 \mathrm{MJ} \mathrm{ME} /$ $\mathrm{kg}$ DM. However, if the LCFB paddock was cut within 30 days of closure then the silage quality was assumed to be $11 \mathrm{MJ} \mathrm{ME} / \mathrm{kg} \mathrm{DM}$. After cutting, silage was also added to the feed store while accounting for ensiling losses of $15 \%$. Between the 1 February and the 30 April a paddock was topped whenever it had a cover $>4500$ paddock to decay. Both dry cows and milkers were fed pasture to meet demand (if available) according to the prescribed break size and minimum residual. If there was a pasture deficit on a specific day, supplements were fed (in the following order) to meet demand from the available feed stores until they were depleted: grass silage from the $11 \mathrm{MJ} M E$ feed store, grass silage from the $10 \mathrm{MJ} \mathrm{ME}$ feed store, maize silage, and PKE. Supplements were fed from the feed stores allowing for wastage of $20 \%, 25 \%$ and $30 \%$ for pasture silage, maize silage and PKE, respectively. Maize silage and PKE feed stores were replenished at the end of each year and the costs accounted for in the calculations of operating profit. Operating Profit, as used here, is defined as the dairy operating return after an allowance for the value of change in: dairy livestock numbers; non-paid labour and management; supplementary feed inventory change; owned run-off adjustment and depreciation.

Cow management policies in the WFM were used to mimic the actual management at NARF regarding breeding, removal of cows from pasture on wet soils, winter grazing, drying off and culling.

\section{Simulations}

Each of the three silage making options was run for each of the three sites and for the two pasture types over 3 consecutive years with as many historical 3-year climate sequences as could be provided for each site. It was important to run the simulations over 3 consecutive years because it accounted for the carry-over effects of pasture yield, covers, feed stores and cow condition from year to year. A total of 5, 9 and 13 unique 3-year climate sequences were available for Dargaville, Whangarei and NARF respectively, resulting in a total $\mathrm{kg} \mathrm{DM} / \mathrm{ha}$. The topped grass biomass was left in the

number of 162 simulations over the three silage making options, three sites and two pasture types. The model estimated pasture yield, milk production, feed costs and operating profit for each year of the 3-year simulations (486 data points), and these were then subjected to further statistical analysis.

\section{Data Analysis}

Data were analysed using analysis of variance, with pasture type (ryegrass-clover and ryegrass-cloverkikuyu), silage making option (LCFB, BCFB and BCVB) and climate site (Whangarei, Dargaville and NARF) and their interactions as treatment factors. The 3 -year climate sequences were considered as replicates. The GenStat 14.1 programme (VSN International 2011) was used. Production (kg MS and kg DM grown per hectare), supplement cost and operating profit were the variables investigated.

\section{Results}

Operating profit: The interaction between silagemaking option and site showed the LCFB option was $\$ 100$ more profitable than the bulk cut treatments, but only at the Whangarei site $(\mathrm{P}<0.05)$. There were no significant differences in operating profit between any of the other options at the other sites (Table 1).

Pasture yield: The LCFB option resulted in a higher pasture yield compared to the bulk cut treatments at both the NARF and Whangarei sites $(\mathrm{P}<0.05)$ (Table 2).

Milk production: Milk solids production was not affected by site or silage-making option.

Total supplement cost: The LCFB option had the lowest supplementary feed costs $(\$ 958 \pm 8 / \mathrm{ha})$ of the three options. The BCFB had costs of $\$ 987 /$ ha and the BCVB option \$992/ha.

The LCFB option made more silage and of a higher quality overall than the bulk cut options. Therefore, although the cost of making the silage was higher, the average cost of the silage on a MJ ME basis was lower for the LCFB option (Table 3).

\section{Discussion}

Table 3. Predicted total silage made (kg DM/ha) and the cost of making (\$/ha and $\$ / \mathrm{MJ} M E)$ for three silage making options: Bulk cut, fixed break size (BCFB), Bulk cut, variable break size (BCVB) and Light cut, fixed break size (LCFB).

\begin{tabular}{lccc}
\hline & \multicolumn{3}{c}{ Silage Making Option } \\
& BCFB & BCVB & LCFB \\
\hline Total $10 \mathrm{MJ}$ ME/kg DM silage made (kg DM/ha) & 47798 & 49950 & 31226 \\
Total $11 \mathrm{MJ}$ ME/kg DM silage made (kg DM/ha) & 8518 & 8464 & 29866 \\
Energy value of total silage made (MJ ME/ha) & 571677 & 592605 & 640796 \\
Average cost of silage making (\$/ha) & 10862 & 11099 & 11438 \\
Average cost of silage making (\$/MJ ME) & 0.019 & 0.019 & 0.018 \\
\hline
\end{tabular}


There was a trend for the LCFB option to produce higher pasture yields and operating profit at all sites, reaching significance at the Whangarei site. Milk production for the LFCB option was not higher than the BCFB and BCVB options at any site. The trend was also for the LFCB option to have a lower total cost of supplements (making silage plus buying imported feeds) compared to the bulk cut options. The two positives of the LCFB option, pasture growth stimulation and silage quality, were countered to a large extent by the higher cost of silage cutting. However, if the amount of energy harvested is considered, then the cost of harvesting the silage (on a MJ ME/ha basis) is lower for the LCFB option.

In most instances the decision to alter rotation length was associated with a decision to alter the pasture intake level per animal, intakes increasing when the grazing rotation was shortened and decreasing when the rotation was lengthened (Matthews et al. 1999). In the LCFB scenario, the rotation length of the farm system did not change as a result of conservation decisions. A paddock was cut as soon as the conservation decision rules in the model identified a pasture surplus and the paddock soil moisture level allowed cutting machines to enter without soil or plant damage. After cutting, the paddock was then returned to the grazing round. In the BCFB scenario, the rotation length did change i.e., it was shortened on the rest of the farm because part of the grazing area was closed for a period of time (to allow the "bulking up" of the pasture). While the pasture quality on the non-conserved area should remain high, the later cutting date is likely to affect feed intake, energy level and digestibility of the silage once it is fed (Marsh \& Ward 1978; McGrath et al. 1999; Randby et al. 2012).

Short rotations (19-25 days) in early spring have been shown to increase feeding levels and production after calving, but reduce average pasture cover and slow pasture growth resulting in poorer feeding of the herd in late spring (Beukes et al. 2006; Bryant 1990). Conversely, these researchers concluded that long spring rotations penalised feeding levels and production in early lactation more than was compensated for by having extra pasture available in late spring.

There was no impact on milk production as stocking rate was kept constant between the different conservation treatments and feed deficits were filled with supplements.

Results from the current work indicated that farmers have flexibility around when and how they close up and cut surplus pasture for silage, as results were not consistent across all sites. It may be that the conservation policy used is less important than the farmers' individual set-up for surplus management, i.e., skills to monitor pasture covers, the use of silage making to control pasture quality, contractor availability and method of ensiling (pit versus bales).

\section{Conclusion}

The hypothesis that the LCFB option was more profitable than the bulk cut options for surplus pasture management was rejected as it was not consistently true for the sites and pasture types modelled here. There were minor differences in key farm performance indicators with different surplus management options. The choice of any surplus pasture management option will be driven by considerations other than profitability, e.g., contractor availability and timeliness, and none of the tested silage making options can be recommended as the most profitable across different climatic sites and pasture types for the Northland region.

Farmers can implement flexible pasture conservation practices to help balance competing demands on labour and other resources without incurring much risk of loss in profit.

\section{REFERENCES}

Beukes, P.C.; Lee, J.M.; Lancaster, J.A.S.; Roche, J.R. 2006. Modelling the impact of changing the decision to graze from rotation length to ryegrass leafstage. Proceedings of the New Zealand Grassland Association 68: 275-281.

Beukes, P.C.; Palliser, C.C.; Macdonald, K.A.; Lancaster, J.A.S.; Levy, G.; Thorrold, B.S.; Wastney, M.E. 2008. Evaluation of a whole-farm model for pasture-based dairy systems. Journal of Dairy Science 91: 2353-2360.

Bryant, A. M. 1990. Present and future grazing systems. Proceedings of the New Zealand Society of Animal Production 50: 35-38.

DairyNZ. 2010. Facts and Figures for New Zealand Dairy Farmers. Accessed: 01/05/2012 http://www. dairynz.co.nz/Publications/FactsFigures/2010/ pp19

Hanigan, M.; Palliser, C.; Gregorini, P. 2009. Altering the representation of hormones and adding consideration of gestational metabolism in a metabolic cow model reduced prediction errors. Journal of Dairy Science 92: 5043-5056.

McCall, D.G.; Bishop-Hurley, G.J. 2003. A pasture growth model for use in a whole-farm dairy production model. Agricultural Systems 76: 11831205

McGrath, J.M.; Penno, J.W.; Davis, K.L.; Wren, R. 1999. Effect of date and length of closure and post grazing residual on pasture quality for silage. Proceedings of the New Zealand Grassland Association 60: 259-264 
Marsh, R.; Ward, J.D.B. 1978. Effect of date of harvest and conservation method on the feeding value of conserved pasture for beef cattle at pasture. Proceedings of the New Zealand Society of Animal Production 38: 191-195

Matthews, P.N.P.; Harrington, K.C.; Hampton, J.G. 1999. Management of grazing systems. pp 153-174. In: New Zealand pasture and crop science. Eds. White, J.; Hodgson, J. Oxford University Press, Sydney
Randby, A.T.; Weisbjerg, M.R.; Norgaard, P.; Heringstad, B. 2012. Early lactation feed intake and milk yield responses of dairy cows offered grass silages harvested at early maturity stages. Journal of Dairy Science 95: 304-317

VSN International. 2011. GenStat for Windows 14th Edition. VSN International, Hemel Hempstead, UK. Web page: GenStat.co.uk 
